\title{
Do Exchange Rate Changes Have Symmetric or Asymmetric Effects on the Demand for Money in Korea?
}

\author{
MOHSEN BAHMANI-OSKOOEE \\ University of Wisconsin-Milwaukee *
}

\author{
JUNGHO BAEK \\ University of Alaska Fairbanks
}

\begin{abstract}
Previous studies of demand for money in Korea assumed that the exchange rate elasticity of the demand for money in Korea were symmetric for appreciations and depreciations, in both sign and size. In this paper we separate Won appreciations from depreciations and find that the assumption is not justified. In the short-run, the sign and size of the effect is different for appreciations compared to depreciations. In the long run, however, only the size of the elasticities differ and both won appreciations and won depreciations lead to an increase in demand for foreign currency
\end{abstract}

Keywords: Nonlinear ARDL Approach, Symmetry versus Asymmetry, Money Demand, Korea.

JEL Classifications: F31, F40

\section{Introduction}

In assessing the effectiveness of fiscal and monetary policies, the Nobel laureate Robert Mundell (1963, p. 484) was the first to conjecture that the demand for money could depend upon the exchange rate in addition to interest rate and income. Although Mundell (1963) did not elaborate too much, nor did he tested his conjecture empirically, others in the literature have tried to justify his hypothesis. Arango and Nadiri (1981) argued that an appreciation of foreign currency (or depreciation of domestic currency) raises domestic currency value of foreign assets held by domestic residents. If this increase is perceived as an increase in wealth, due to an increase in consumption, the demand for money could also increase. On the other hand,

\footnotetext{
* Bahmani-Oskooee: The Center for Research on International Economics, Department of Economics, University of Wisconsin-Milwaukee; bahmani@uwm.edu . Baek: Department of Economics, School of Management, University of Alaska Fairbanks; jbaek3@alaska.edu.

Valuable comments of two anonymous referees and those of the editor are greatly appreciated. Remaining errors, however, are our own.

(C) 2017 Mohsen Bahmani-Oskooee and Jungho Baek. Licensed under the Creative Commons Attribution - Noncommercial 3.0 Licence (http://creativecommons.org/licenses/bync/3.0/. Available at http: //rofea.org.
} 
Bahmani-Oskooee and Pourheydarian (1990) argued that when foreign currency appreciates, if there are expectations of further appreciation, domestic residents may buy and hold more of foreign currency and less of domestic currency. The strength of each effect (wealth versus substitution) is a matter of empirical analysis and in general is country specific, as evidenced from the literature. Examples of studies that have included the exchange rate in their specification of the demand for money are: Arango and Nadiri (1981) for Canada, Germany, UK., the US., Domowitz and Elbadawi (1987) for Sudan, Marquez (1987) for Venezuela, Bahmani-Oskooee and Malixi (1991) for 13 developing countries, Karfakis (1991) for Greece, McNown and Wallace (1992) for the U.S., Bahmani-Oskooee (1996) for Iran, BahmaniOskooee and Techaratanachai (2001) for Thailand, Civcir (2003) and Bahmani-Oskooee and Karacal (2006) for Turkey, Harb (2004) for six oil producing countries, Bahmani-Oskooee and Gelan (2009) for African countries, Bahmani-Oskooee and Xi (2011) for Australia, BahmaniOskooee et al. (2012) for China, and Bahmani-Oskooee et al. (2013) for emerging countries.

There are also a few studies that have estimated the demand for money in Korea after including the exchange rate. The list includes Bahmani-Oskooee and Rhee (1994), Lee and Chung (1995), and Bahmani-Oskooee and Shin (2002). While, the first study has used EngleGranger (1987) method, the second one has relied upon Johansen's technique. Finally, the last study employed Pesaran et al.'s (2001) bounds testing approach under which variables could be combination of $I(0)$ and $I(1){ }^{1}$

No matter which cointegration method is used to estimate the demand for money in Korea or in any other country, the implicit assumption is that all determinants have symmetric effects. Concentrating on the exchange rate, the symmetry assumption implies that if depreciation raises the demand for money, say due to relatively strong wealth effect, appreciation should lower it. Recently, Bahmani-Oskooee and Bahmani (2015) argued that this may not be the case due to changes in market participants' expectations. By estimating the demand for money for Iran, they demonstrated that indeed exchange rate changes have asymmetric effects. Our goal in this paper is to test symmetry versus asymmetry hypothesis in Korean demand for money. To that end, we outline the model and methods in Section II. Section III reports the results supporting asymmetry effects. While Section IV concludes, data sources are cited in the Appendix.

\section{The Models and Methods}

The long-run specification of money demand in this section follows the literature reviewed in the previous section and includes a scale variable, measures of opportunity cost of holding money and the exchange rate as in equation (1):

\footnotetext{
${ }^{1}$ Since M2 is the monetary aggregate that is targeted, almost all studies concentrate on M2 demand for money including those on Korea.
} 
BAHMANI-OSKOOEE, BAEK Exchange Rate Changes and Money Demand in Korea

$$
\operatorname{Ln} M_{t}=a+b \operatorname{Ln} Y_{t}+c \operatorname{Ln} r_{t}+d \operatorname{Ln}\left(P_{t} / P_{t-1}\right)+e \operatorname{LnEX} X_{t}+\varepsilon_{t}
$$

where $M$ is a measure of real quantity of money held by the public and $Y$ is the scale variable measured by the real GDP in Korea. Two measures of opportunity cost of holding money are included in (1). The interest rate denoted by $r$ is a measure of opportunity cost against financial assets and inflation rate measured by $\operatorname{Ln}\left(P_{t} / P_{t-1}\right)$ is the opportunity cost of holding money against real assets. Finally, the nominal effective exchange value of Korean won that is denoted by $E X$ is included to account for currency substitution. While an estimate of $\mathrm{b}$ is expected to be positive, those of $\mathrm{c}$ and $\mathrm{d}$ are expected to be negative. Per discussion in the previous section, if a decline in $E X$, i.e., a depreciation of Korean won is to increase the demand for domestic currency due to relatively stronger wealth effect an estimate of e could be negative. Otherwise, if substitution effect is relatively stronger, an estimate of e could be positive.

Estimating equation (1) by any means only yields long run coefficient estimates. However, as Laidler (1991, pp. 175-176) argued, excluding the short-run adjustment process from estimating long-run coefficients may result in some instability. Therefore, we incorporate shortrun dynamic adjustment process into estimating long-run coefficients by specifying (1) in an error-correction modeling format as follows:

$$
\begin{aligned}
& \Delta L n M_{t}=\alpha+\sum_{i=1}^{n 1} \beta_{i} \Delta \operatorname{Ln} M_{t-i}+\sum_{i=0}^{n 2} \delta_{i} \Delta \operatorname{Ln} Y_{t-i}+\sum_{i=0}^{n 3} \phi_{i} \Delta L n r_{t-i}+\sum_{i=0}^{n 4} \gamma_{i} \Delta \operatorname{Ln}\left(P_{t} / P_{t-1}\right)_{t-i}+ \\
& \sum_{i=0}^{n 5} \eta_{i} \Delta \operatorname{LnEX_{t-i}}+\rho_{0} \operatorname{Ln} M_{t-1}+\rho_{1} \operatorname{Ln} Y_{t-1}+\rho_{2} \operatorname{Ln} r_{t-1}+\rho_{3} \operatorname{Ln}\left(P_{t} / P_{t-1}\right)_{t-1}+ \\
& \rho_{4} \operatorname{LnE} X_{t-1}+\varepsilon_{t}
\end{aligned}
$$

Specification (2) is due to Pesaran et al. (2001) who recommend applying the familiar $F$ test to establish joint significance of lagged level variables as a sign of cointegration. ${ }^{2}$ However, they also tabulate new critical values for this $F$ test which accounts for integrating properties of variables. If all variables in a given model are $I(1)$, an upper bound critical value is provided. A lower bound critical value is provided when all variables are $I(0)$. Pesaran et al. (2001) demonstrate that the upper bound critical value could also be used if some variables are $I(0)$ and some $I(1)$. Since almost all macro variables are either $I(0)$ or $I(1)$, under this approach there

\footnotetext{
${ }^{2}$ Note that the linear combination of lagged level variables in (2) is a proxy for lagged error term known as error-correction term from (1). Therefore, establishing joint significance of lagged level variables is equal to establishing significance of lagged error-correction term
} 
is no need for pre-unit root testing and this is one of the main advantage of this approach. Another advantage to this bounds testing approach is that the short-run and long-run effects are estimated in one step by applying OLS to equation (2). The short-run effects are reflected in the estimates of coefficients assigned to first-differenced variables. The long-run effects are inferred by the estimates of $\rho_{1^{-}} \rho_{4}$ normalized on $\rho_{0}{ }^{3}$

As pointed out by Bahmani-Oskooee and Bahmani (2015), a main assumption in model (2) is that changes in any of the exogenous variables have symmetric effects on the demand for money. For example, concentrating on the effects of nominal effective exchange rate changes, the assumption implies that if depreciation of Korean won increases the demand for won in Korea, appreciation should lower it, yielding a negative normalized elasticity in (2). To test this hypothesis, we follow the literature and try to separate depreciations from appreciations. To do so, we first generate changes in the $L n E X$ variable as $\triangle L n E X$. From this new time-series variable which includes zero values, negative values, and positive values, we construct the partial sum of negative and positive values as follows:

$$
\begin{aligned}
& \operatorname{LnEX}_{t}^{+}=\sum_{j=1}^{t} \Delta \operatorname{LnEX_{j}^{+}}=\sum_{j=1}^{t} \max \left(\Delta \operatorname{LnEX} X_{j}, 0\right), \\
& \operatorname{LnEX} X_{t}^{-}=\sum_{j=1}^{t} \Delta \operatorname{LnEX} X_{j}^{-}=\sum_{j=1}^{t} \min \left(\Delta \operatorname{LnEX} X_{j}, 0\right) .
\end{aligned}
$$

where $L n E X^{+}{ }_{t}$ and $L n E X_{t}{ }_{t}$ are the partial sum process of positive and negative changes in $L n$ $E X$. The next step is to go back to error-correction model (2) and replace $L n E X$ by two new variables that we have just generated, i.e., $\operatorname{Ln} E{X^{+}}^{+}$and $L n E X^{-}{ }_{t}$ as follows:

$$
\begin{aligned}
\Delta \operatorname{Ln} M_{t}=a+ & \sum_{i=1}^{n 1} b_{i} \Delta \operatorname{Ln} M_{t-i}+\sum_{i=0}^{n 2} c_{i} \Delta \operatorname{Ln} Y_{t-i}+\sum_{i=0}^{n 3} d_{i} \Delta \operatorname{Ln} r_{t-i}+\sum_{i=0}^{n 4} e_{i} \Delta \operatorname{Ln}\left(P_{t} / P_{t-1}\right)_{t-i}+ \\
& \sum_{i=0}^{n 5} f_{i} \Delta \operatorname{LnEX_{t-i}^{+}}+\sum_{i=0}^{n 6} g_{i} \Delta \operatorname{LnEX} X_{t-i}^{-}+\theta_{0} \operatorname{Ln} M_{t-1}+\theta_{1} \operatorname{Ln} Y_{t-1}+\theta_{2} L n r_{t-1}+ \\
& \theta_{3} \operatorname{Ln}\left(P_{t} / P_{t-1}\right)_{t-1}+\theta_{4} \operatorname{LnEX_{t-1}^{+}}+\theta_{5} \operatorname{LnEX_{t-1}^{-}}+\xi_{t}
\end{aligned}
$$

\footnotetext{
${ }^{3}$ For more details of normalization, see Bahmani-Oskooee and Tanku (2008) and for applications in other areas see. Halicioglu, F., (2007), Narayan et al. (2007), Tang (2007), Mohammadi et al. (2008), Wong and Tang (2008), De Vita and Kyaw (2008), Payne (2008), Chen and Chen (2012), and Hajillee and AlNasser (2014).
} 


\section{BAHMANI-OSKOOEE, BAEK Exchange Rate Changes and Money Demand in Korea}

Since constructing the new partial sum variables introduce non-linearity into specification (5), Shin et al (2014) label such models as nonlinear ARDL model and demonstrate that all statistical features of this nonlinear model is the same as linear ARDL model of Pesaran et. al (2001). More precisely, Pesaran et al (2001) bounds testing approach is equally applicable to nonlinear model (5). If appreciations and depreciations are to have symmetric effects, normalized coefficients obtained for $\operatorname{LnEX^{+}}{ }_{t}$ and $\operatorname{LnEX_{t}}{ }_{t}$ variables must be the same in sign and size. Otherwise, their effects are asymmetric.

\section{The Results}

In this section, we estimate both the linear and nonlinear ARDL models outlined by equations (2) and (5) for Korea using quarterly data over the period 1973:Q3-2014:Q3. Following the literature, we impose a maximum of eight lags on each first differenced variable and estimate different lag permutations. We then use Akaike's Information Criterion (AIC) and select the optimum lags. The results from each optimum model are reported in Tables 1 for linear model and Table 2 for nonlinear model. In each table, short-run estimates are reported in Panel A, the long-run estimates in Panel B, and diagnostic statistics in Panel C.

We first consider the results of the linear model (2) in Table 1. From the short-run estimates in Panel A, it is clear that there is at least one significant coefficient obtained for income and exchange rate, implying that only these two variables have short-run effects on the demand for money in Korea. However, as we shift to the long-run estimates in Panel B, we gather that all variables carry significant coefficients, except the exchange rate. Income elasticity is somewhat greater than one suggesting some economies of scale. Out of two opportunity cost variables, the inflation rate carries its expected negative sign and highly significant coefficient, implying that in Korea real assets are preferred to holding cash. ${ }^{4}$

Next, we must establish cointegration if long-run estimates are to be valid. To this end, we shift to Panel $\mathrm{C}$ and the results of the $\mathrm{F}$ test. Given its critical value of 4.01, clearly our calculated $F$ statistic of 6.81 is highly significant, supporting cointegration. ${ }^{5}$ An alternative test to establish cointegration is to use normalized long-run coefficient estimates from Panel B and long-run model (1) and generate an error term. Labeling this error term as ECM, then replace the linear combination of lagged values in equation (2) by $\mathrm{ECM}_{\mathrm{t}-1}$ and estimate this new specification after imposing the same optimum lags on all first differenced variables. A

\footnotetext{
${ }^{4}$ The positive and significant interest rate elasticity implies that as interest rates rise in Korea, it induces more saving and hence more interest income. This eventually leads to more spending and hence, an increase in the demand for money.

${ }^{5}$ The critical value is from Pesaran et al. (Table CI(iii) Case III, p. 300) where number of exogenous variables is four.
} 
Review of Economic Analysis 9 (2017) 155-168

Table 1: Full Information Estimate of Linear ARDL Equation (2)

\begin{tabular}{lcccccc}
\hline \multicolumn{7}{l}{ Panel A: Short-Run Coefficient Estimates } \\
\hline \multicolumn{7}{c}{ Lag Order } \\
\hline \multirow{5}{*}{$\Delta \ln M$} & 0 & 1 & 2 & 3 & 4 & 5 \\
\cline { 2 - 6 } & - & -0.033 & 0.321 & -0.140 & 0.261 & -0.087 \\
$\Delta \ln Y$ & -0.118 & -0.001 & 0.001 & -0.182 & & \\
& $(1.670)^{*}$ & $(0.037)$ & $(0.040)$ & $(2.842)^{* *}$ & & \\
$\Delta \ln \left(P_{\mathrm{t}} / P_{\mathrm{t}-1}\right)$ & -0.019 & & & & & \\
$\Delta \ln E X$ & $(0.104)$ & & & & \\
& 0.062 & -0.043 & -0.108 & 0.076 & & \\
$\Delta \ln r$ & $(1.511)$ & $(0.729)$ & $(1.797)^{*}$ & $(1.807)^{*}$ & & \\
& -0.002 & & & & & \\
\hline
\end{tabular}

Panel B: Long-Run Coefficient Estimates

\begin{tabular}{ccccc}
\hline Constant & $\ln Y$ & $\ln \left(P_{\mathrm{t}} / P_{\mathrm{t}-1}\right)$ & $\ln E X$ & $\Delta \ln r$ \\
\hline 29.358 & 1.541 & -14.464 & -0.376 & 0.450 \\
$(14.091)^{* *}$ & $(8.683)^{* *}$ & $(2.951)^{* *}$ & $(1.289)$ & $(3.073)^{* *}$ \\
\hline
\end{tabular}

Panel C: Diagnostic Statistics

\begin{tabular}{ccccccc}
\hline$F$ & $E C M_{\mathrm{t}-1}$ & $L M$ & RESET & Normality & $\begin{array}{c}C U S \\
\left(C U S^{2}\right)\end{array}$ & Adj. $R^{2}$ \\
\hline $6.81^{*}$ & $\begin{array}{c}-0.063 \\
(3.009)\end{array}$ & 1.449 & 2.116 & 4.456 & Stable & 0.638 \\
\hline
\end{tabular}

Notes:

a. Numbers inside the parentheses are absolute values of the $t$-ratios.

b. The upper bound critical value of the F-statistic at the 5\% significance level is 4.01 (when there are four exogenous variables). This comes from Pesaran et al. (2001, Table CI-Case III, p. 300).

c. The upper bound critical value of the t-statistic at the 5\% (10\%) significance level is -3.99 (3.66) when there are four exogenous variables. These come from Pesaran et al. (2001, Table CIICase III, p. 303). These values are used to judge significance of $\mathrm{ECM}_{\mathrm{t}-1}$.

d. LM and RESET are the Lagrange multiplier test of serial correlation and Ramsey's test for functional form. The normality test is based on a test of skewness and kurtosis of residuals. All three tests are distributed as $\chi^{2}$. While the first two have one degree of freedom, the normality test has two degrees of freedom. The critical values at the 5\% significance level is 3.89 for one degree of freedom and 5.99 for two degrees of freedom.

e. ${ }^{* *}$ and $*$ denote significance at the $5 \%$ and $10 \%$ levels, respectively. 
BAHMANI-OSKOOEE, BAEK Exchange Rate Changes and Money Demand in Korea

Table 2. Full Information Estimate of Nonlinear ARDL Equation (5)

Panel A: Short-Run Coefficient Estimates

\begin{tabular}{|c|c|c|c|c|c|c|}
\hline & \multicolumn{6}{|c|}{ Lag Order } \\
\hline & 0 & 1 & 2 & 3 & 4 & 5 \\
\hline$\Delta \ln M$ & - & $\begin{array}{c}0.087 \\
(1.198)\end{array}$ & $\begin{array}{c}0.291 \\
(4.184)^{* *}\end{array}$ & $\begin{array}{l}-0.093 \\
(1.373)\end{array}$ & $\begin{array}{c}0.311 \\
(4.717)^{* *}\end{array}$ & $\begin{array}{c}-0.181 \\
(2.610)^{* *}\end{array}$ \\
\hline$\Delta \ln Y$ & $\begin{array}{c}0.079 \\
(3.635)^{* *}\end{array}$ & & & & & \\
\hline $\begin{array}{l}\Delta \ln \left(P_{t} / P_{t-}\right. \\
\left.{ }_{1}\right)\end{array}$ & $\begin{array}{c}0.059 \\
(0.323)\end{array}$ & & & & & \\
\hline$\Delta \ln E X^{+}$ & $\begin{array}{c}0.295 \\
(2.745)^{* *}\end{array}$ & & & & & \\
\hline$\Delta \ln E X^{-}$ & $\begin{array}{c}0.026 \\
(0.533)\end{array}$ & $\begin{array}{c}0.056 \\
(1.125)\end{array}$ & $\begin{array}{c}-0.073 \\
(1.559)\end{array}$ & $\begin{array}{c}0.041 \\
(0.858)\end{array}$ & $\begin{array}{l}-0.065 \\
(1.404)\end{array}$ & $\begin{array}{c}0.011 \\
(0.237)\end{array}$ \\
\hline$\Delta \ln r$ & $\begin{array}{l}-0.031 \\
(1.387)\end{array}$ & & & & & \\
\hline
\end{tabular}

Panel B: Long-Run Coefficient Estimates

\begin{tabular}{cccccc}
\hline Constant & $\ln Y$ & $\ln \left(P_{\mathrm{t}} / P_{\mathrm{t}-1}\right)$ & $\ln E X^{+}$ & $\ln E X^{*}$ & $\Delta \ln r$ \\
\hline 26.148 & 1.818 & -13.109 & 4.905 & -0.041 & 0.435 \\
$(42.491)^{* *}$ & $(17.879)^{* *}$ & $(3.575)^{* *}$ & $(2.465)^{* *}$ & $(0.021)$ & $(3.083)^{* *}$ \\
\hline
\end{tabular}

Panel C: Diagnostic Statistics

\begin{tabular}{|c|c|c|c|c|c|c|c|c|}
\hline$F$ & $E C M_{\mathrm{t}-1}$ & $L M$ & RESET & Normality & $C U S\left(C U S^{2}\right)$ & Adj. $R^{2}$ & Wald-S & Wald-L \\
\hline $6.64 * *$ & $\begin{array}{l}-0.060 \\
(4.16)^{* *}\end{array}$ & 0.363 & 3.082 & 3.160 & Stable & 0.621 & $4.055^{*}$ & 0.085 \\
\hline
\end{tabular}

Notes:

a. Numbers inside the parentheses are absolute values of the $t$-ratios.

b. The upper bound critical value of the F-statistic at the $5 \%$ significance level is 4.01 (when there are four exogenous variables). This comes from Pesaran et al. (2001, Table CI-Case III, p. 300).

c. The upper bound critical value of the t-statistic at the $5 \%(10 \%)$ significance level is -4.19 (3.86) when there are five exogenous variables. These come from Pesaran et al. (2001, Table CIICase III, p. 303). These values are used to judge significance of $\mathrm{ECM}_{\mathrm{t}-1}$.

d. LM and RESET are the Lagrange multiplier test of serial correlation and Ramsey's test for functional form. The normality test is based on a test of skewness and kurtosis of residuals. All three tests are distributed as $\chi^{2}$. While the first two have one degree of freedom, the normality test has two degrees of freedom. The critical values at the 5\% significance level is 3.89 for one degree of freedom and 5.99 for two degrees of freedom.

e. ${ }^{* *}$ and $*$ denote significance at the $5 \%$ and $10 \%$ levels, respectively. 
significantly negative coefficient obtained for $\mathrm{ECM}_{\mathrm{t}-1}$ will support cointegration and size of the coefficient in absolute value will measure the speed of adjustment. Banerjee et al. (1998) who have proposed this test for establishing cointegration demonstrated that the distribution of the $t$ statistic for testing significance of $\mathrm{ECM}_{\mathrm{t}-1}$ is non-standard, hence they tabulate new critical values. Indeed, building upon Banerjee et al. (1998), Pesaran et al. (2001) show that just like the $F$ test, this $t$ statistic also has an upper and a lower bound critical values within their ARDL approach that they tabulate. ${ }^{6}$ Given their upper bound critical value of $-3.99(-3.66)$ at the $5 \%$ (10\%) significance level, clearly the coefficient is insignificant.

We have also reported several additional diagnostics in Panel C. In order to assess serial correlation and functional misspecification, we have conducted the Lagrange Multiplier (LM) and Ramsey's RESET tests. They are both distributed as $\chi^{2}$ with one degree of freedom. Given its critical value of 3.89 , our reported statistics are insignificant, suggesting that the optimum model is correctly specified with autocorrelation free residuals. We also use a test of skewness and kurtosis of residuals to see if the residuals are normally distributed. It has a $\chi^{2}$ distribution with two degrees of freedom. Given its critical value of 5.99 at the $5 \%$ level of significance, this statistic is also insignificant, supporting the normality assumption. We also test the hypothesis of whether the money demand in Korea is stable. To establish stability of short-run and long-run coefficient estimates, again, we follow the literature and apply the well-known CUSUM and CUSUMSQ tests to the residuals of the optimum model. ${ }^{7}$ As indicated in Panel $\mathrm{C}$ by CUS and CUS ${ }^{2}$, indeed all estimates are stable. Finally, to measure goodness of fit, we report the size of adjusted $R^{2}$.

As discussed above, we found that the nominal effective exchange rate had no long-run effects on the demand for money in Korea. Could this be due to assuming asymmetric effects? Do the results change if we shift to nonlinear model and separate currency depreciations from appreciations? To that end, we move to Table 2. From the short-run results in Panel A, we gather that appreciation of Korean won has significant short-run effects but depreciation does not. These short-run effects seem to be asymmetric in nature. Furthermore, we also observe short-run adjustment asymmetry due to the fact that $\Delta L n E X^{+}{ }_{t}$ and $\Delta L n E X_{t}^{-}$take different lag orders. Shin et al. (2014) also recommend testing for short-run 'impact asymmetry' by establishing the fact that sum of the short-run coefficients obtained for $\triangle L n E X^{+}{ }_{t}$ are significantly different than sum of the coefficients associated with $\triangle L n E X^{*}$. In terms of notations used in nonlinear model we establish short-run impact asymmetry if $\sum f \neq \sum g$. The Wald test is the recommend test. Indicating this statistic by Wald-S in Panel C of Table 2,

\footnotetext{
${ }^{6}$ See Pesaran et al. (2001, Table CII, p. 303).

${ }^{7}$ For a graphical presentation of these tests see Bahmani-Oskooee and Bohl (2000) and BahmaniOskooee et al. (2005).
} 


\section{BAHMANI-OSKOOEE, BAEK Exchange Rate Changes and Money Demand in Korea}

it is clear that this statistic is significant at the 5\% level, supporting significance of short-run asymmetry effects of exchange rate changes on the demand for money in Korea. Do these shortrun asymmetry effects translate into the long run?

The long-run results indicate that indeed the long-run effects of won appreciation $\left(\operatorname{Ln} E X^{+}{ }_{t}\right)$ and won depreciation $\left(\operatorname{LnEX^{-}}{ }_{t}\right)$ are asymmetric. While, the first one carries significantly positive coefficient, the later one carries an insignificant coefficient estimate. But are the two estimates significantly different? Again, Shin et al. (2014) recommend applying the Wald test. Our calculated Wald statistic is denoted by Wald-L in Panel C of Table 2 is insignificant rejecting long-run asymmetry effects. ${ }^{8}$ The fact that $\operatorname{LnEX^{+}}$ carries significantly positive coefficient implies that, as won appreciates against foreign currencies (or foreign currencies such as the U.S. dollar depreciates), Koreans hold more of domestic currency and less of foreign currency, supporting expectation effect. If we were to rely upon only the linear model, since the exchange rate was insignificant in the long run, we would have concluded that it has no long-run effects. However, when nonlinear adjustment of the exchange rate is incorporated into the model, clearly won appreciation has significant long run effects on the demand for money in Korea. Such findings are in contrast to those of Bahmani-Oskooee and Bahmani (2015) who estimated similar models using data from post-revolutionary Iran. Since after the revolution and due to sanctions Iranians cannot hold assets abroad, the long-run asymmetric effects was argued to be due to expectation effect. This is because Iranians always expected the exchange rate of the dollar to appreciate, regardless of the current changes in the exchange rate. In fact, the dollar between 1979 and 2017 the exchange rate of the dollar has appreciated from 70 rials to almost 37000 rials per dollar. So even if, at times, the dollar depreciates, there is an expectation it will appreciate in the future.

Once again, for the long-run effects to be meaningful we must establish cointegration. Due to interdependence between the two partial sum variables Shin et al. (2014, p. 291) recommend using the critical values for the $\mathrm{F}$ test for four exogenous variables (in the linear model) rather than five (in the nonlinear model) since the critical values for four variables are higher. Clearly, our significant $\mathrm{F}$ statistic supports cointegration and our long-run analysis. In this nonlinear model, $\mathrm{ECM}_{\mathrm{t}-1}$ is also highly significant which was not the case in the linear model. This provides not just additional support for cointegration but also supports nonlinear adjustment and the nonlinear model. Apparently, almost $6 \%$ of the adjustment takes place within one quarter since data are quarterly. ${ }^{9}$ Remaining diagnostics are similar to those of the linear model supporting lack of autocorrelation, correct specification, and normality of the residuals.

\footnotetext{
${ }^{8}$ Note that in terms of our notations in Model (5) we establish long-run asymmetry if $\theta_{4 \neq} \theta_{5}$. We also carried out the analysis for M1 demand for money and found no significant long-run asymmetric effects.

${ }^{9}$ Note that the upper bound critical value of t-test to justify significant of ECMt-1 when there are five exogenous variables is $-4.19(-3.86)$ at the $5 \%(10 \%)$ significance level. These come from Pesaran et al.(2001, Table CII, p. 303).
} 
The major finding so far is that the exchange rate changes do not have any long-run effect on the demand for money in Korea from the linear model (Table 1). However, when appreciations are separated from depreciations, won appreciation has long-run effects but won depreciation does not (Table 2). In generating the two measures of appreciation and depreciation we included small and large exchange rate changes by selecting the threshold value in equations (3) and (4) to be zero. What if we consider appreciations of more than $1 \%$ and depreciations of less than $-1 \%$. To this end, we replace threshold value of zero by 1 in equation (3) and by -1 in (4) and generate the new partial sum variables and carry out the estimation one more time. The results are reported in Table 3.

Clearly, Table 3 reveals that both large appreciations and large depreciations do have shortrun and long-run effects on the demand for money in Korea, in an asymmetric manner. Shortrun impact asymmetry and long-run asymmetric effects are now supported by the Wald-S and Wald-L statistics. The fact that asymmetry cointegration is supported by both the F and $\mathrm{ECM}_{\mathrm{t}}$ 1 test validates significant positive coefficients obtained for $L n E X+$ and $L n E X$-variables in Panel B of Table 3. These positive estimates imply, once more, that won depreciation induces speculative attack against won by reducing the demand for won. Alternatively, won appreciation raises the demand for won, all in line with expectation effect.

\section{Summary and Conclusion}

Applied research is usually revisited when a new econometric method is introduced. As time goes on, due to additional contributions in each area, each country begins having its own literature, especially when the models use time-series data. The demand for money is no exception and is perhaps one of the areas in monetary theory that has received greatest attention. Several authors have considered the Korean demand for money and have applied different methods and have addressed different issues such as determinants of the money demand and its stability.

No matter which method is used to estimate the demand for money in Korea, a common feature of all studies is that they have assumed the effects of each determinant to be symmetric. In this paper we ask whether the impact of exchange rate changes on the demand for money in Korea is symmetric or asymmetric. Depreciation of Korean won could induce Koreans to hold more won if wealth effect is stronger or it could induce them to hold less won and more foreign currency if substitution effect is stronger. Since substitution effect is based on expectations and expectations change over time, we would expect the effects of exchange rate changes on the demand for money to be asymmetric. Put it differently, if $1 \%$ appreciation raises the demand for money by $2 \%, 1 \%$ depreciation may not lower the demand for money by $2 \%$ if public's expectation change in favor of holding foreign currency due to intervention by central banks in the foreign exchange market. Like previous research, when we estimated a linear ARDL model, 
BAHMANI-OSKOOEE, BAEK Exchange Rate Changes and Money Demand in Korea

Table 3. Full Information Estimate of Nonlinear ARDL for Appreciations (depreciations) of More (less) than $1 \%$.

\begin{tabular}{|c|c|c|c|c|c|c|}
\hline & \multicolumn{6}{|c|}{ Lag Order } \\
\hline & 0 & 1 & 2 & 3 & 4 & 5 \\
\hline$\Delta \ln M$ & - & $\begin{array}{c}0.097 \\
(1.273)\end{array}$ & $\begin{array}{c}0.300 \\
(4.135)^{* *}\end{array}$ & $\begin{array}{l}-0.042 \\
(0.557)\end{array}$ & $\begin{array}{c}0.357 \\
(4.964)^{* *}\end{array}$ & $\begin{array}{c}-0.138 \\
(1.837)^{*}\end{array}$ \\
\hline$\Delta \ln Y$ & $\begin{array}{c}0.069 \\
(2.938)^{* *}\end{array}$ & $\begin{array}{c}-0.077 \\
(2.178)^{* *}\end{array}$ & $\begin{array}{c}-0.030 \\
(1.360)\end{array}$ & & & \\
\hline$\underset{1}{\Delta \ln \left(P_{t} / P_{t-}\right.}$ & $\begin{array}{c}-0.338 \\
(1.766)^{*}\end{array}$ & & & & & \\
\hline$\Delta \ln E X^{+}$ & $\begin{array}{c}0.045 \\
(0.885)\end{array}$ & $\begin{array}{c}0.173 \\
(3.388)^{* *}\end{array}$ & $\begin{array}{c}-0.005 \\
(1.131)\end{array}$ & $\begin{array}{c}-0.007 \\
(1.825)^{*}\end{array}$ & $\begin{array}{c}-0.00 \\
(0.318)\end{array}$ & $\begin{array}{c}-0.009 \\
(2.261)^{* *}\end{array}$ \\
\hline$\Delta \ln E X^{-}$ & $\begin{array}{c}-0.053 \\
(1.049)\end{array}$ & $\begin{array}{c}-0.170 \\
(3.320)^{* *}\end{array}$ & & & & \\
\hline$\Delta \ln r$ & $\begin{array}{c}0.003 \\
(0.136)\end{array}$ & $\begin{array}{c}-0.036 \\
(1.622)\end{array}$ & & & & \\
\hline
\end{tabular}

Panel B: Long-Run Coefficient Estimates

\begin{tabular}{cccccc}
\hline Constant & $\ln Y$ & $\ln \left(P_{\mathrm{t}} / P_{\mathrm{t}-1}\right)$ & $\ln E X^{+}$ & $\ln E X^{-}$ & $\Delta \ln r$ \\
\hline-18.457 & 1.514 & -9.335 & 0.020 & 0.010 & 0.348 \\
$(2.289)^{* *}$ & $(5.871)^{* *}$ & $(5.169)^{* *}$ & $(1.971)^{* *}$ & $(2.021)^{* *}$ & $(3.516)^{* *}$ \\
\hline
\end{tabular}

Panel C: Diagnostic Statistics

\begin{tabular}{|c|c|c|c|c|c|c|c|}
\hline$F$ & $E C M_{\mathrm{t}-1} \quad L M$ & RESET & Normality & $C U S\left(C U S^{2}\right)$ & Adj. $R^{2}$ & Wald-S & Wald-L \\
\hline $7.68 * *$ & $\begin{array}{l}-0.1300 .218 \\
(5.173) * *\end{array}$ & 3.499 & 0.257 & Stable & 0.624 & $3.451 *$ & $6.28 * *$ \\
\hline
\end{tabular}

Notes:

a. Numbers inside the parentheses are absolute values of the $t$-ratios.

b. The upper bound critical value of the F-statistic at the 5\% significance level is 4.01 (when there are four exogenous variables). This comes from Pesaran et al. (2001, Table CI-Case III, p. 300).

c. The upper bound critical value of the t-statistic at the $5 \%(10 \%)$ significance level is $-4.19(-3.86)$ when there are five exogenous variables. These come from Pesaran et al. (2001, Table CII-Case III, p. 303). These values are used to judge significance of $\mathrm{ECM}_{\mathrm{t}-1}$.

d. LM and RESET are the Lagrange multiplier test of serial correlation and Ramsey's test for functional form. The normality test is based on a test of skewness and kurtosis of residuals. All three tests are distributed as $\chi 2$. While the first two have one degree of freedom, the normality test has two degrees of freedom. The critical values at the 5\% significance level is 3.89 for one degree of freedom and 5.99 for two degrees of freedom.

e. $* *$ and $*$ denote significance at the $5 \%$ and $10 \%$ levels, respectively. 
the exchange rate only had short-run but not long-run effects. However, when we shifted to nonlinear ARDL model and separated depreciations from appreciation, not only we found evidence of short-run adjustment asymmetry, but also short-run significant impact asymmetry effects. In the long-run however, both won appreciation and won depreciations have significant effects on the demand for money but in a symmetric manner. Additional diagnostics supported the nonlinear model better than the linear mode. Apparently, in Korea won depreciations raises the demand for domestic currency, supporting the wealth effect. This unique finding was masked by previous research and any linear model.

\section{Appendix: Data Definition and Sources}

Quarterly data over the period 1973:Q3-2014:Q3 are used d to conduct the empirical analysis. The data sources are as follows:

a. International Financial Statistics of the IMF (www.imfstatistics.org).

b. Bank for International Settlements (www.bis.org).

\section{Variables:}

$\mathrm{M}=$ Real money supply measured by M2. Nominal M2 is deflated by GDP deflator (source a).

$\mathrm{Y}=$ Real GDP (source a).

$\mathrm{P}=$ Consumer Price Index (source a).

EX $=$ Nominal effective exchange rate (source b). A decline reflects a depreciation of Korean won.

$r=$ interest rate defined as government bond yield (5-year National Housing Bonds)(source a).

\section{References}

Arango, Sebastian, and M. Ishaq Nadiri (1981), Demand for Money in Open Economies, Journal of Monetary Economics, Vol. 7, pp. 69-83.

Bahmani-Oskooee, M. (1996), The Black Market Exchange Rate and Demand for Money in Iran, Journal of Macroeconomics, Vol. 18, pp. 171-176.

Bahmani-Oskooee, Mohsen and Mohammad Pourheydarian, (1990). Exchange Rate Sensitivity of the Demand for Money and Effectiveness of Fiscal and Monetary Policies, Applied Economics, 22 pp. 1377-1384.

Bahmani-Oskooee, Mohsen and Hyun-Jae Rhee (1994), Long-Run Elasticities of the Demand for Money in Korea: Evidence from Cointegration Analysis, International Economic Journal, Vol. 8, pp. 83-93.

Bahmani-Oskooee, M. and M. Bohl (2000) German Unification and the Stability of Long-Run German Money Demand Function, Economics Letters, Vol. 66, pp. 203-208. 
BAHMANI-OSKOOEE, BAEK Exchange Rate Changes and Money Demand in Korea

Bahmani-Oskooee, M. and A. Tacharatanachai (2001), Currency Substitution in Thailand, Journal of Policy Modeling, Vol. 23, pp. 141-145.

Bahmani-Oskooee, M. and S. Shin (2002), Stability of the Demand for Money in Korea, International Economic Journal, Vol. 16, pp. 85-95.

Bahmani-Oskooee, M. and M. Karacel (2006), The Demand for Money in Turkey and Currency Substitution, Applied Economics Letters, Vol. 13, pp. 635-642.

Bahmani-Oskooee, M. and A. Tanku, (2008), The Black Market Exchange Rate vs. the Official

Rate in Testing PPP: Which Rate Fosters the Adjustment Process, Economics Letters, Vol. 99, pp. 40-43.

Bahmani-Oskooee, M. and A. Gelan, (2009), How Stable is the Demand for Money in African Countries, Journal of Economic Studies, Vol. 36, pp. 216-235.

Bahmani-Oskooee, M. and D. Xi, (2011), Economic Uncertainty, Monetary Uncertainty and the Demand for Money in Australia Australian Economic Papers, Vol. 50, pp. 115-128.

Bahmani-Oskooee, M. and S. Bahmani (2015), "Nonlinear ARDL Approach and the Demand for Money in Iran", Economics Bulletin, Vol. 35, pp. 381-391.

Bahmani-Oskooee, M., Y. Wang, and D Xi, (2012), Economic Uncertainty, Monetary Uncertainty and the Demand for Money in China, The Chinese Economy, Vol. 45, pp. 2637.

Bahmani-Oskooee, M., C. Economidou, and G. G. Goswami., (2005), How Sensitive are Britain's Inpayments and Outpayments to the Value of the British Pound, Journal of Economic Studies. Vol. 32, pp. 455-467.

Bahmani-Oskooee, M., A. Kutan, and D. Xi, (2013), The Impact of Economic and Monetary Uncertainty on the Demand for Money in Emerging Economies, Applied Economics, Vol. 45, pp. 3278-3287.

Chen, Shyh-Wei and Tzu-Chun Chen, (2012) Untangling the Non-Linear Causal Nexus between Exchange Rates and Stock Prices: New Evidence from the OECD Countries, Journal of Economic Studies, Vol. 39, pp. 231-25.

Civcir, I. (2003), Money Demand, Financial Liberalization and Currency Substitution in Turkey, Journal of Economic Studies, Vol. 30, pp. 514-534.

De Vita, G. and K. S. Kyaw, (2008), Determinants of Capital Flows to Developing Countries: A Structural VAR Analysis, Journal of Economic Studies, Vol. 35, pp. 304-322.

Domowitz, I. and I. Elbadawi (1987), An Error-Correction Approach to Money Demand: The Case of Sudan, Journal of Development Economics, Vol. 26, pp. 257-275.

Hajilee, Massomeh, and Omar M. Al-Nasser, (2014), Exchange Rate Volatility and Stock Market Development in Emerging Economies, Journal of Post Keynesian Economics, Vol. 37, pp. 163-180.

Halicioglu, F., (2007), The J-Curve Dynamics of Turkish Bilateral Trade: A Cointegration Approach, Journal of Economic Studies, Vol. 34, pp. 103-119. 
Harb, N. (2004), Money Demand Function: A Heterogeneous Panel Application, Applied Economics Letters, Vol. 11, pp. 551-555.

Karfakis, C.I. (1991), Monetary Policy and the Velocity of Money in Greece: A Cointegration Approach, Applied Financial Economics, Vol. 1, pp. 123-127.

Laidler, E.W.D. (1993) The Demand for Money: Theories Evidence and Problems, $4^{\text {th }}$ Edition, Harper Collins College Publishers

Lee, Tong Hun, and Keun Jon Chung, (1995), Further Results on the Long-Run Demand for Money in Korea: A Cointegration Analysis, International Economic Journal, Vol. 9, pp. 103-113.

Marquez, J. (1987), Money Demand in Open Economies: A Currency Substitution Model for Venezuela, Journal of International Money and Finance, Vol. 6, pp. 167-178.

McNown, R. and M.S. Wallace (1992) Cointegration Tests of a Long-Run Relationship between Money Demand and the Effective Exchange Rate Journal of International Money and Finance 11, 107-114

Mohammadi, H., M. Cak, and D. Cak, (2008), Wagner's Hypothesis: New Evidence from Turkey using the Bounds Testing Approach, Journal of Economic Studies, Vol. 35, pp. 94106.

Mundell, A. Robert (1963), Capital Mobility and Stabilization Policy under Fixed and Flexible Exchange Rates, Canadian Journal of Economics and Political Science, Vol. 29, pp. 475485.

Narayan, P.K., S. Narayan, B.C. Prasad, and A. Prasad, (2007), Export-led Growth Hypothesis: Evidence from Papua New Guinea and Fiji, Journal of Economic Studies, Vol. 34, pp. 341351.

Payne, J. E., (2008), Inflation and Inflation Uncertainty: Evidence from the Caribbean Region, Journal of Economic Studies, Vol. 35, pp. 501-511.

Pesaran, M. H.' Y. Shin, and R. J. Smith, (2001), Bounds Testing Approaches to the Analysis of Level Relationships, Journal of Applied Econometrics, Vol.16, pp. 289-326.

Shin, Y, B. C. Yu, and M. Greenwood-Nimmo (2014) Modelling Asymmetric Cointegration and Dynamic Multipliers in a Nonlinear ARDL Framework Festschrift in Honor of Peter Schmidt: Econometric Methods and Applications, eds. by R. Sickels and W. Horrace: Springer, 281-314.

Tang, T.C., (2007), Money Demand Function for Southeast Asian Countries: An Empirical View from Expenditure Components, Journal of Economic Studies, Vol. 34, pp. 476-496.

Valadkhani, Abbas, Modelling Demand for Broad Money in Australia, Australian Economic Papers, Vol. 44 (2005), pp. 47-64.

Wong, K. N.. and T. C. Tang, (2008) The Effects of Exchange Rate Variablity on Malaysia's Disaggregated Electrical Exports, Journal of Economic Studies, Vol. 35, pp. 154-169. 